\title{
A STUDENT-CENTERED APPROACH TO THE AMERICAN SURVEY
}

Lee A. Gladwin

Carnegie-Mellon University

In recent years classroom calm has been disturbed by criticism from various sectors. Demands for greater relevance, learning for the future and career preparation come immediately to mind. Alvin Toffler warns teachers "to recognize that the acceleration of change--in technology, in family structure, marriage and divorce patterns, mobility rates, division of labor, in urbanization, ethnic and subcultural conflict, and international relations--means, by definition, the swift arrival of a future that is radically different from the present." 1 Perhaps the most important reasons for change are those expressed by students openly or through classroom performance. The teacher must constantly review and revise courses in light of these and other challenges. All too often his changes are knee-jerk responses to specific problems which, by narrowing the focus, can lead to ineffectual adjustments unguided by any rationale. Secondary teachers may receive courses in educational philosophy, principles, and methods without perceiving the dynamic relationship between them. College teachers lack even this. They may nod through a lecture on the philosophy of history from the metaphysics of Kant to the idealism of Croce, but there is rarely a suggestion that such knowledge may have practical applications to teaching. The result in either case is the isolation of theory from practice. It is only natural that later difficulties are reacted to by reflex rather than reflection.

To illustrate the effects of course changes based upon both knee-jerk responses and upon readings in the philosophy of history, two personal experlences will be described. In part, the problems confronting me stemmed from the dual nature of Shenandoah College and Conservatory of Music in Winchester, Virginia, which recruits music students primarily. Stimulating interest and learning in competition with the many demands of their music courses was most difficult. Academic subjects such as the survey of United States History traditionally received low priority among ardent oboists and zealous xylophonists. Some years ago, a freshman complained, "I just don't have three hours every night,to spend reading history since I'm in the conservatory." While nothing could be done about the composition of classes, the content and presentation of the course provided unlimited possibilities for revolutionary tinkering. After eight years of adjusting lectures, tests, texts, and audiovisual presentations, much was altered but nothing changed. Tests revealed little understanding of course themes and no transference of learning from assigned readings. Another round of revision was.inspired by a reading of William Glasser's Schools Without Failure (New York, 1969). Perhaps the answer was to give the student greater autonomy. A new set of instructions required that the student contract both to read a specific number of books for the desired grade and to pass objective examinations. Questions were written to measure understanding of themes rather than memorization of trivia, and the tests were graded on a pass/fail basis. Lecture outlines and a list of books related to the themes were also distributed. It was hoped that the outlines would provide a framework for organization of readings and lecture notes. Still, interest and learning, as measured by the examinations, remained less than remarkable. Lowering the amount of required book reviews and allowing failed examinations to be made up by writing additional reviews raised grades but depressed test scores. After yet another phrenetic session at the drawing board, role-playing was introduced. This had the positive effect of giving a sense of participation in the past and was well received by several students, but transference of learning from role preparations to tests did not occur.

While contemplating the spectre of second semester, I happened to read Car1 Becker's Everyman His Own Historian and R. G. Collingwood's The Idee of History. Through these and other teadings, a wider perspective and a sense of direction were achieved. There was Becker warning that Everystudent "is 
stronger than we are, and sooner or later we must adapt our knowledge to his necessities." Anticipating Toffler, he wrote "that every generation... will, must inevitably, understand the past and anticipate the future in the light of its own restricted experience" and seek "to understand what it is doing in the light of what it has done and what it hopes to do." His definition of history "as an imaginative reconstruction of vanished events" was helpful to arriving at a personal definition for the purpose of course revision. ${ }^{2}$ Collingwood's discussion of the historian's need for concern with both the "inside" and "outside" of an event suggested an approach to instruction from the "inside," the student's perception of the effects of the past upon him. 3 How could he take an interest in a past which texts and lectures presented as "outside" his experience rather than as an extention of it?

Based upon such observations, new requirements were prepared which called upon the student to write a "series of papers dealing with historical change." They were to range from two to five pages in length, and each would explore a different decade guided by answering specific questions: "What events and changes have affected my present and future? How have they contributed to my life-style, quality of life, values, goals, etc.?" Some social, economic, and technological topics were listed along with the political. Finally, the student was told that the papers would be "cumulative in effect and a final paper must be written summarizing the events which you believe have most influenced your life today." A second sheet provided assignments for each decade including suggested sources and additional questions. In order to immediately engage student interest, the first assignment was the 1960s. Each student was to consult such sources as Life, Newsweek, and the New York Times using the month and day of his birth and the years 1960, 1964, and 1968 as common starting places. In every decade, general questions concerning such things as changing images and values in advertisements were supplemented by more specific ones dealing with particular individuals and events. For the 1950 s students reviewed "the career of Richard Nixon" and examined "the impact of Sputnik." A question in the 1940s assignment asked about "the long-range results of the war." Similar examples could also be given for the 1930 s and 1920s. Research was immediately reinforced by class discussion. A schedule of topics was announced to allow students to gear their research to each upcoming class. The first topic might be politics or world affairs, and the last was usually elite and popular culture. Classes were often begun with a filmstrip from the American Decades series, which lends itself to a topical approach. 4 Finding no suitable filmstrip to introduce the World War II homefront, a special slide and tape program was compiled from various pictorial histories and contemporary phonograph records. Despite the unprofessional quality of the program, it was quite well received by students. Such aids helped students fit their findings into a broader context and provided a quick review prior to discussion.

To my great joy, would-be musicians discovered the library contained more than scores and records and began regular pilgrimages to the stacks. One told me of spending five hours on a single assignment! Lively and informed discussions were no longer exceptional, though there was some slackening as we moved into decades where research had to replace personal memory. Continuity and change in values as reflected by pre-war and post-war generations were among the topics stimulating the widest interest and participation.

At semester's end, we had reached only the 1920s, and I completed the survey back to the Civil War through lectures centered around some of the themes emerging from our discussions. The growth and organization of industry, the alliance of business and government, and the efforts at reform and regulation were among them. During this time, each student received final instructions for writing the summary paper. He was told to choose "one or more themes which you believe have had the greatest meaning for you and you generation." Next, he was required to justify his choice "by arguing its importance and 
demonstrating its significance." Lastly, he received the following reminder: "This paper should demonstrate your ability to recognize and analyze historical developments and to write about them in a clear and logical manner. It should also show a fundamental grasp of research and writing." After allowing a couple of days to select topics, one class was dedicated to individual conferences for the purpose of refining various choices.

On the whole, the final results of the new approach were favorable. The last papers generally reflected greater interest on the part of students and were vastly improved in quality over the earliest efforts. Although the grade average rose from a 1.2 first semester to a 2.0 for second semester students completing the course (based on a 4.0 scale), the best indicator of increased learning is seen in the results of a non-credit, unannounced test given during examination week. As an additional precaution, students were told not to put their names on the answer sheet. In order to better compare the new approach with the one used the previous year, the same fifty-question objective test was given. Whereas eighty per cent of the forty who took it in 1975 scored below sixty, only seventy-five per cent of the twelve taking it in 1976 did so. This does not sound terribly impressive until it is remembered that the latter group was not expecting an examination and did not have as many lectures as the previous class. After deleting eighteen questions which were not touched upon during the 1976 semester, the average grade rose to a phenomenal $81 \%$. Transference of learning had taken place, and this group exceeded the other in their understanding of the recent past.

In addition to the examination, unsigned evaluations were also requested. First, students were asked, "Has the course helped you to gain insight into contemporary life?" Typical of the responses were the following: "It has helped [me] greatly to see exactly how the people thought back then in their own words instead of being told facts of what happened. It has also helped me to tie together in sequence what happened in history." Another believed the research helped him "to see how things have changed \& with each decade what influenced the change." Some actually discovered history could be mildly interesting: "By looking at each decade through the papers, I could see that history is not as cut and dry [sic] as I believed." Only one, a student teacher pressed for time, replied in the negative; but even this had a positive side. After admitting a preference for the lecture-testing method ("I can study my notes easier than finding time to go to the library."), she acknowledged that independent study "made me very aware of certain things . . . that we did not get out of lectures." Asked to choose between lecture-testing and independent study methods, the rest of the class chose the latter. One commented, "I understand it better myself and can become interested in it personally." Another wrote that independent study was "extremely effective in showing the continuum of events. The class showed how events lead to further events, not just single happenings which had no effect on developments in other areas (social, cultural, \& economic)."

No method is infallible and there were several suggestions for +. rovements. Some thought more lectures were needed to provide better background. A special session on organizing and writing research papers was another proposal. Not wholly unexpected were complaints about the lack of time to do the extra work involved. Unlike previous years, however, some students made an effort to find time: "I found some of my researching to be very interesting, and if it had not been for this method I would not have taken the time to do it. So thanks!" To these I would add that discussion might have been improved by counting it as part of the grade.

The foregoing is not intended as an argument for general adoption of either the method or the philosophy behind it. What is urged here is the value of a knowledge of the philosophy of history to the teacher as he confronts the 
problem of semester preparations. In a recent work combining philosophy with methodology, Lester D. Stephens declares, "I believe wholeheartedly that to teach history well, the teacher must possess a thorough understanding of the nature of historical inquiry." 5 If the history teacher is to be more than a technician, his preparations should be informed by philosophy. At some point he must tentatively answer the question, "What is history?" If he does not, how can he describe without definition or clarify without contemplation?

\section{NOTES}

${ }^{1}$ Alvin Toffler, ed., Learning for Tomorrow: The Role of the Future in Education (New York, 1974), 4.

2

Everyman His Own Historian (Chicago, 1966), 251-253.

3 The Idea of History (New York, 1946), 213-215.

${ }^{4}$ This series covers the entire period from 1920 to 1970 . It is available through Educational Audio Visual Inc., Pleasantville, New York 10570.

5 Probing the Past: A Guide to the Study and Teaching of History (Boston, 1974), xi. Another effort in this direction is Henry Steele Commager's The Nature and the Study of History (Columbus, Ohio, 1965). 